\title{
Influence of bed materials on the performance of the Nong Bua dual fluidized bed gasification power plant in Thailand
}

\author{
Vilailuck Siriwongrungson $^{1} \cdot$ Janjira Hongrapipat ${ }^{2} \cdot$ Matthias Kuba $^{3,4} \cdot$ Reinhard Rauch $^{5} \cdot$ Shusheng Pang ${ }^{6}$. \\ Jullapong Thaveesri ${ }^{7} \cdot$ Michael Messner $^{2} \cdot$ Hermann Hofbauer $^{4}$
}

\begin{abstract}
Bed materials and their catalytic activity are two main parameters that affect the performance of the dual fluidized bed (DFB) gasification system in terms of product gas composition and tar levels. Two sources of bed materials were used for the operation of a commercial DFB gasification system in Thailand, using woodchips as a biomass feedstock. One source of the bed materials was the calcined olivine which had been used in the Gussing Plant, Austria, and the other activated bed material was a mixture of fresh Chinese olivine and used Austrian olivine with additives of biomass ash, calcium hydroxide and dolomite. These bed materials were collected and analysed for morphological and chemical composition using a scanning electron microscopy (SEM), energy dispersive spectroscopy (EDS) and X-ray fluorescence spectroscopy (XRF). The product gas was cleaned in a scrubber to remove tars, from which the samples were collected for gravimetric tar analysis. Its composition data was automatically recorded at the operation site before it entered the gas engine. From the SEM, EDS and XRF analyses, calcium-rich layers around the bed materials were observed on the activated bed material. The inner layers of bed materials collected were homogeneous. Biomass ash, which was generally added to the bed materials, had significant calcium and potassium content. These calcium-rich layers of the bed materials, from the calcium hydroxide, biomass ash and dolomite, influenced system performance, which was determined by observing lower tar concentration and higher hydrogen concentration in the product gas.
\end{abstract}

Keywords Dual fluidized bed · Olivine $\cdot$ Catalyst activity $\cdot$ Calcium layer · Gasification

\section{Introduction}

Due to depletion of fossil fuels and environmental concerns from an extensive use of the fossil fuels, biomass has been recognized as a promising renewable energy resource whose

Vilailuck Siriwongrungson

vilailuck.si@kmitl.ac.th

1 College of Advanced Manufacturing Innovation, King Mongkut's Institute of Technology Ladkrabang, Bangkok, Thailand

2 Güssing Renewable Energy (Thailand) Co. Ltd, Bangkok, Thailand

3 Bioenergy2020+ GmbH, Wienerstraße 49, 7540 Gussing, Austria

4 Institute of Chemical Engineering, TU Wien, Vienna, Austria

5 Fuel Technology, Engler-Bunte-Institut, Karlsruhe Institute of Technology, Karlsruhe, Germany

6 Department of Chemical and Process Engineering, University of Canterbury, Christchurch, New Zealand

7 Ministry of Industry, Bangkok, Thailand use has increased in recent years [1-4]. Biomass is considered a carbon-neutral energy source, as carbon dioxide is absorbed through photosynthesis in plant growing and is then released from the biomass during its utilization in the production of heat and electricity via gasification and combustion $[5,6]$. Thailand is an agricultural country with an estimated biomass generation of more than $130 \mathrm{Mt}$ per year, while $60 \mathrm{Mt}$ per year has been consumed for energy production [7]. These biomass resources can be used to produce not only energy but also chemical products and synthetic fuels [3]. Biomass steam gasification technology has advanced rapidly since late 2001 [5, $8,9]$, when the demonstration plant went into operation in Gussing town, Austria. The dual fluidized bed (DFB) gasification technology demonstrated in Gussing has been used to produce a product gas, which can be further utilized for the production of power or synthetic fuels such as hydrogen, synthetic natural gas (BioSNG), dimethyl ether (DME), biomethane, Fischer-Tropsch diesel or mixed alcohols. However, the product gas needs to be cleaned of tars to various low levels depending on the final product $[2,6,9]$. 


\subsection{DFB gasification system}

The DFB gasification system uses steam as the gasification agent, and gasification occurs in the absence of air [4]. The raw product gas from the gasification process is mainly comprised of hydrogen $\left(\mathrm{H}_{2}\right)$, carbon monoxide $(\mathrm{CO})$, carbon dioxide $\left(\mathrm{CO}_{2}\right)$, methane $\left(\mathrm{CH}_{4}\right)$ and light hydrocarbons, as well as some contaminants such as entrained fine particles of char, ash and fine bed materials, as well as heavy hydrocarbons. These heavy hydrocarbons are commonly known as tars $[2,6,9]$. The product gas from the DFB gasification system has a notably high lower heating value (LHV) of $12-14 \mathrm{MJ} / \mathrm{Nm}^{3}$ (dry gas) and an extremely high hydrogen content compared with, for example, air gasification processes [5]. This is because with steam as the gasification agent, hydrogen is generated from steam gasification reactions (such as water-gas shift reaction and steam-methane reforming reaction), and extremely low levels or zero nitrogen $\left(\mathrm{N}_{2}\right)$ is present in the product gas.

In the DFB gasification system, a fast fluidized bed (FFB) combustion reactor is used in which char generated from gasification is combusted to heat up the circulating material which supplies heat to the endothermic steam gasification in the bubbling fluidized bed (BFB) gasification reactor. Air injected into the FFB reactor acts as the combustion medium, while steam acts as the fluidization medium and the reactant in the BFB gasification reactor. With appropriate surface composition, the bed material acts not only as the heat carrier but also as a catalyst to enhance tar reforming and promote certain gasification reactions $[3,4,10,11]$.

The DFB gasification system, first developed by the Vienna University of Technology (VUT) [9] at a scale of $100 \mathrm{~kW}_{\text {th }}$, has been commercialized successfully in Europe and Thailand [11]. The first power plant with this DFB technology was installed in Gussing, Austria, in 2001, with a capacity of $8 \mathrm{MW}_{\text {th }}$ (denoted as "Gussing Plant" in this article). It has been operating successfully since then. Following this, more power plants using DFB gasification technology have been installed, including the $8.5 \mathrm{MW}_{\text {th }}$ fuel power in Oberwart, Austria; the $15 \mathrm{MW}_{\text {th }}$ in Villach, Austria; the 16 $\mathrm{MW}_{\text {th }}$ in Senden, Germany; and the $32 \mathrm{MW}_{\text {th }}$ in Gothenburg, Sweden [5, 9, 12-14]. Recently, a 3.8 $\mathrm{MW}_{\text {th }}$ prototype of the DFB gasifier was built and commissioned in Thailand with new engineering design and improvements on certain equipment, i.e. biomass dryer, gasifier design, tar scrubber design and heat exchanger system. With these improvements, the new plant in Thailand can handle various biomass feedstocks such as woodchips, sugarcane leaf, corn cobs, cassava rhizomes and many others [15].

\subsection{Tars}

In biomass gasification, tars in the product gas are undesirable. They condense and cause problems in pipes, heat exchangers and other downstream process equipment when the product gas is cooled down $[1,5,6,8]$. Therefore, one of the objectives in the biomass gasification operation is to reduce tar concentration in the product gas. Tars are defined as organics, produced under thermal or partial oxidation regimes (gasification) of any organic material and are generally assumed to be largely aromatics [9]. They are often classified as primary tars, secondary tars and tertiary tars. In general, primary tars or heterocyclic components such as pyridine, phenol and cresols are formed in biomass gasification. At high gasification temperatures, these heterocyclic tars recombine into heavier molecules, which are referred to as secondary tars or light aromatics. Examples of light aromatics and polyaromatics are styrene, naphthalene, acenaphthylene, phenanthrene, fluorene and anthracene. Finally, the secondary tars are recombined into tertiary tars or heavy polyaromatics. Examples of these tertiary tars include fluoranthene and pyrene [9]. Tar concentration and composition depend on the type of fuel, gasification temperature, residence time, gasification agent, steam-to-carbon ratio when steam is used as the gasification agent and any catalysts that may be present [16]. The operating temperature is a strong influencing parameter regarding the formation and decomposition of tars [17]. Nevertheless, the minimum limit of tar concentration in the product gas depends on the product gas applications [8]. Considerable research effort has been put into finding ways to remove tars from the product gas effectively and economically. These methods may be divided into primary methods, which occur in the gasifier, and secondary methods, which are applied downstream of the gasification reactor [1].

For primary tar reduction in the gasifier, a catalyst can be used to enhance the tar reforming reaction pathway of biomass gasification according to Le Chatelier's principle, which is related to gas composition, reaction temperature and operating pressure [5]. It has been reported that tars could be reduced at high gasification temperatures, but the temperature is limited by the ash melting point, determined by the properties of the biomass feedstock and bed material [6]. The use of catalytically active calcined olivine or catalysts has been reported as a typical primary method to reduce the tar concentration in the product gas $[4,16]$. The use of bed materials should be economically feasible and, at the same time, should enhance or at least not inhibit the formation of useful gaseous species and increase the heating value [16]. In addition, the use of catalytically active calcined olivine is a state of the art for biomass gasification using the DFB gasification system [18]. The catalyst influences plant performance in terms of product gas composition and its heating value.

\subsection{Bed materials}

In recent studies, a number of bed materials and catalysts have been used for tar reduction in biomass gasification processes 
$[19,20]$. Among the most studied materials are dolomite/ calcined dolomite [21], olivine/calcined olivine [6, 22, 23], alkali feldspars [24-26] and calcium-based catalysts such as limestone [27] and calcium oxide [28]. Metal-based catalysts such as $\mathrm{Ni}, \mathrm{Co}, \mathrm{Pt}, \mathrm{Rh}$ and $\mathrm{Ru}$, including Ni-olivine, have also been investigated for conversion of tars to hydrogen and light hydrocarbon gases and for increasing the olivine tar reforming activity [29-33]. It is reported that olivine, as a bed material, generates four to six times less dust than dolomite in flue gas in DFB gasification because dolomite particles suffer higher attrition in the fluidized bed process [20,34]. However, dolomite shows 1.4 times higher tar removal efficiency than olivine $[5,23]$. In addition, dolomite is a well-known, natural, inexpensive additive, which is disposable and can be calcined. However, when used in fluidized bed gasification, it softens and thus suffers higher attrition [20, 23, 35].

On the other hand, olivine, as a natural and disposable bed material, is not expensive, has high tar reforming activity as well as strong mechanical resistance, even at high temperatures. Therefore, olivine is suitable as a bed material in DFB gasification $[3,23,36]$. Olivine consists mainly of magnesium oxide, iron oxide and silica $\left((\mathrm{Mg}, \mathrm{Fe})_{2} \mathrm{SiO}_{4}\right)$, whereas the major components of dolomite are calcium and magnesium carbonate $\left((\mathrm{Ca}, \mathrm{Mg}) \mathrm{CO}_{3}\right)$ [1]. Olivine from different locations may have slightly different compositions, which fall into various groups according to its composition. These groups include fayalite, iron-rich silicate $\left(\mathrm{Fe}_{2} \mathrm{SiO}_{4}\right)$, forsterite, magnesium-rich $\left(\mathrm{Mg}_{2} \mathrm{SiO}_{4}\right)$ and other minerals [19, 21, 33]. Olivine activity, or to be more specific, olivine activation, was reported to be dependent on the iron oxide content [22, 37-39]. With the olivine treatment temperature, the iron structure can be presented in the olivine phase or as iron oxides $\left(\mathrm{Fe}_{2} \mathrm{O}_{3}\right)[40]$.

In addition to the iron oxides, magnesium oxide $(\mathrm{MgO})$ has also been reported to be related to the activity of olivine [36]. Once an ash layer has formed through the interaction of the bed particles with the biomass ash, calcium (most likely as calcium oxide $(\mathrm{CaO})$ at the surface of the layer) is another key component of the catalyst [41]. SEM images of unused calcined olivine, used calcined olivine and a magnified SEM image of the used calcined olivine from the study of Kirnbauer and Hofbauer [42], as shown in Fig. 1, reveal that the calciumrich layer was clearly observed on the outer layer of the used calcined olivine. However, such a calcium-rich layer was not found on the unused calcined olivine.

It is also noted that, in general, the catalyst is deactivated when its active sites are covered and no longer available due to the deposition of char or coke on the surface. Although catalytic bed materials have been widely used and investigated for tar reduction in biomass gasification, the exact mechanism on gasification performance under different operational conditions in one commercial-scale plant, where the operating conditions may differ from other commercial-scale plants, has not yet been comprehensively investigated. It is anticipated that the chemical composition of the catalytic bed material can be influenced by gasification conditions [4, 42].

\subsection{Purposes of this study}

This study will investigate the influence of catalytic bed materials on the product gas composition and tar concentration of a commercial-scale 3.8-MW $\mathrm{MW}_{\text {th }}$ DFB gasification system in Thailand where woodchips are used as the biomass fuel. Surface morphology and compositional mapping of the bed materials collected from the gasifier will be analysed. The bed materials analysed were the used calcined olivine from Gussing, Austria, and the purchased calcined olivine from China mixed with additives, which will be described in this article as "used Austrian olivine" and "layered Chinese olivine", respectively. The local proximity and availability of bed materials (calcined olivine purchased from China) is of importance to the operation in Thailand. Therefore, the calcined olivine from a source not far away has strategic advantages and has never been investigated before. The results from these analyses will be used to establish a benchmark for further comparison with gasification of other agricultural residues typical for the operation in Thailand, and Asia in general. Fly ash composition is also analysed regarding the previously reported components $\mathrm{Ca}, \mathrm{Si}, \mathrm{Fe}, \mathrm{Mg}, \mathrm{K}$ and $\mathrm{P}$ [43]. Moreover, fly ash has been reported to be rich in unconverted carbon [6].
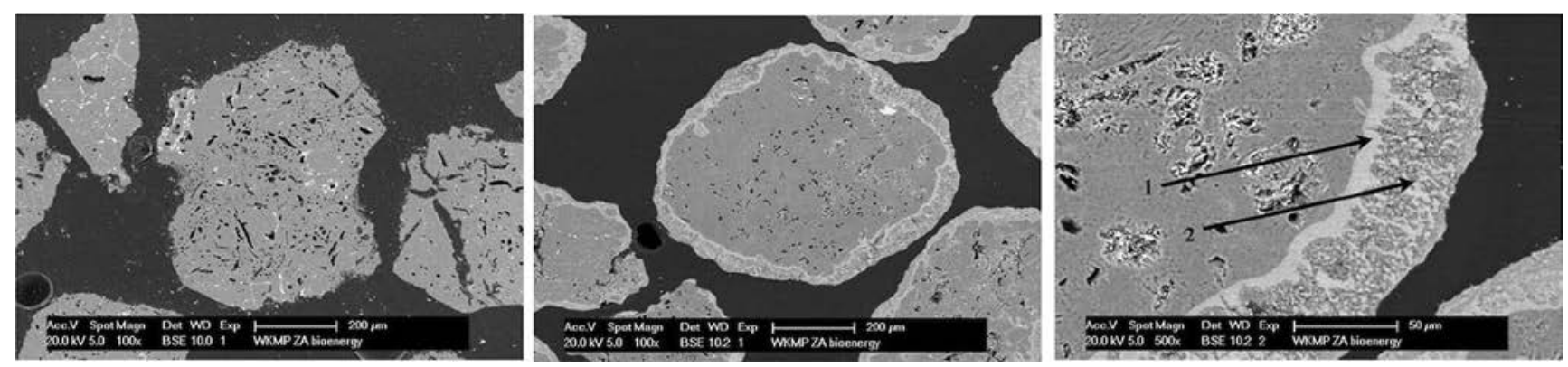

Fig. 1 SEM images of unused calcined olivine (left), used calcined olivine (centre) and a SEM image at higher magnification of the used calcined olivine (right) showing an inner layer (1) and outer catalytic layer (2) [42] 


\section{Material and methods}

\subsection{Bed materials and additives}

Bed materials used in this study were mainly calcined olivine sand, which is iron and magnesium orthosilicate $((\mathrm{Mg}$, $\mathrm{Fe})_{2} \mathrm{SiO}_{4}$ ). It can be classified into two samples, denoted as "used Austrian olivine" and "layered Chinese olivine", regarding the bed material activity.

The used Austrian olivine is the used calcined olivine obtained from the Gussing Plant in Austria. The fresh calcined olivine, before used in the Gussing Plant, was sourced from Austria and, according to its specification, was a magnolite with a particle size of $0.3-0.8 \mathrm{~mm}$. Its chemical composition analysed by the Magnolithe $\mathrm{GmbH}$ is shown in Table 1 . The used Austrian olivine has been utilized many times during hot tests at the Nong Bua Plant since April 2017.

The layered Chinese olivine is the used Austrian olivine after it has been utilized many times for hot tests, mixed with calcined olivine purchased from China (denoted as "fresh Chinese olivine") with the addition of calcium hydroxide $\left(\mathrm{Ca}(\mathrm{OH})_{2}\right)$, biomass ash and dolomite $\left(\mathrm{CaCO}_{3} \cdot \mathrm{MgCO}_{3}\right)$. The fresh Chinese olivine has a particle size between 0.3 and 0.8 $\mathrm{mm}$. Its analysed composition by the Minchem Materials (Tianjin) Import \& Export Co., Ltd. is summarized in Table 1. The layered Chinese olivine was used for a total of $34.5 \mathrm{~h}$ operating time after the successful hot tests in December 2017.

\subsection{Dual fluidized bed (DFB) gasification system principles}

The dual fluidized bed (DFB) gasification system used for this research project has been reported in literature with its schematic diagram shown in Fig. 2 [5, 15, 42, 44]. The DFB gasifier is composed of two fluidized bed reactors, which are a bubbling fluidized bed (BFB) gasification reactor (gasifier)

Table 1 Analysed composition in weight percentage (wt \%) of fresh calcined Austrian olivine according to the specification from the Magnolithe $\mathrm{GmbH}$ and fresh calcined Chinese olivine according to the specification from the Minchem Materials (Tianjin) Import \& Export Co., Ltd.

\begin{tabular}{lll}
\hline Component & Fresh Austrian olivine & Fresh Chinese olivine \\
\hline $\mathrm{MgO}$ & $47.5-50.0$ & 45.3 \\
$\mathrm{SiO}_{2}$ & $39.0-42.0$ & 41.8 \\
$\mathrm{CaO}$ & $\leq 0.4$ & N/A \\
$\mathrm{Fe}_{2} \mathrm{O}_{3}$ & $8.0-10.5$ & 9.2 \\
$\mathrm{Al}_{2} \mathrm{O}_{3}$ & N/A & 0.45 \\
$\mathrm{H}_{2} \mathrm{O}$ & N/A & 0.46 \\
Loss on ignition & 0.2 & 0.5 \\
\hline
\end{tabular}

and a fast fluidized bed (FFB) combustion reactor (combustor). The biomass feedstock is fed directly into the gasifier via a screw feeder, where the bed material is fluidized with superheated steam as the gasifying agent. In the combustor, the bed material is fluidized with the input air and heated by the combustion of char and supplementary fuel, when needed, at the operating temperature of $900-950{ }^{\circ} \mathrm{C}$. At the top of the combustor, the flue gas and the hot bed material are separated through a cyclone. Then the hot bed material flows to the gasifier through a loop seal to provide heat to the endothermic biomass steam gasification. The loop seal, or syphon, effectively prevents gas cross-flow between the two reactors and allows high biomass solid throughput. This loop seal and chute also let the solid flow of bed material circulate between the gasifier and the combustor.

When catalytic bed material is used or a catalyst is added, the bed material also enhances steam gasification, tar reforming or tar cracking, in addition to its function as heat carrier from combustion to gasification reactors. The product gas generated from the gasifier flows out of the gasification reactor and is cooled down, using a heat exchanger and recycled gas, to approximately $150-200{ }^{\circ} \mathrm{C}$. It is further filtered in a bag filter to remove the remaining fine particles. Finally, the product gas is cleaned in a scrubber to remove tars, using rapeseed methyl ester (RME) as a tar-scrubbing liquid. For gas analysis, the gas composition is measured after the RME scrubber. More samples of tars were also taken after the RME scrubber via gravimetric and gas chromatography (GC) analyses. The cleaned product gas eventually enters the gas engine or may undertake further treatments if the product gas is used for other applications.

It has been noted that the operating temperature of both reactors is affected by the energy required for gasification, the energy supply from the combustion of char and supplementary fuel and the bed circulation rate. The operating temperature in the gasifier can be self-stabilized because, when the temperature in the gasifier decreases, the amount of residual char increases, which provides more heat in the combustor and delivers more energy to the gasifier [3]. For the commercial-scale plant, the temperature in the gasifier can be controlled by varying the amount of recycled char and tars from the bag filter, the tar-loaded scrubbing liquid, the char from the gasifier and the clean product gas to the combustor.

\subsection{Nong Bua DFB gasification system}

\subsubsection{Description of the Nong Bua DFB gasification system}

In the present study, experiments were performed at the Nong Bua DFB gasification system (denoted as the "Nong Bua Plant" in this article), which has a heat input capacity of 3.8 $\mathrm{MW}_{\text {th }}$ and is located in the Nong Bua District, Nakhonsawan Province, Thailand. The gasifier is 
Fig. 2 Schematic diagram of a DFB gasifier [12]

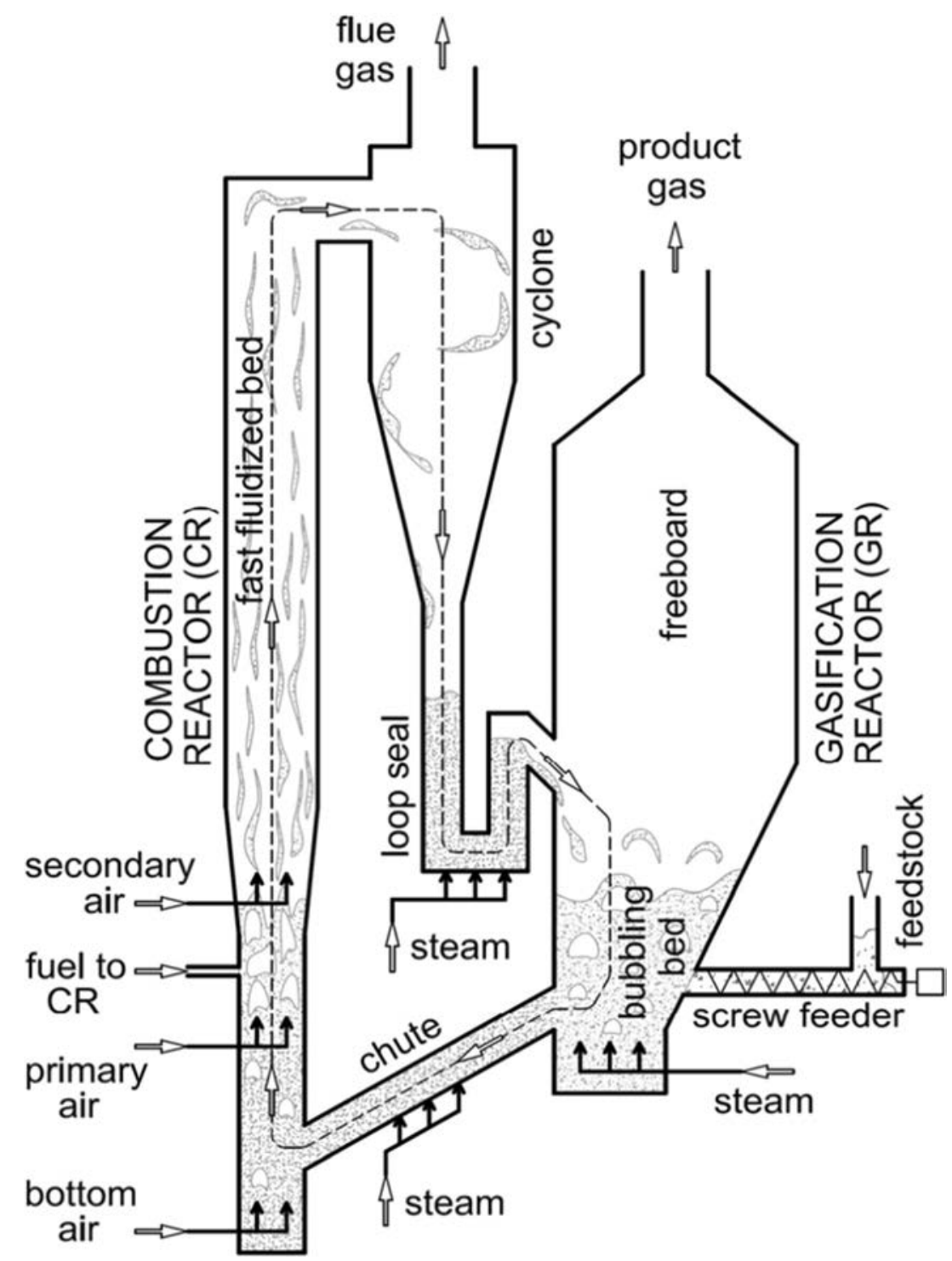

approximately $7 \mathrm{~m}$ high with an external diameter of about $2.8 \mathrm{~m}$, while the combustor is around $10 \mathrm{~m}$ high with an external diameter of about $1 \mathrm{~m}$. The schematic diagram of the Nong Bua Plant is shown in Fig. 3. The process can be described as follows.

Biomass feedstock is fed into the gasifier via a fuel handling system. Then the produced product gas from the gasifier flows into two product gas coolers, a product gas bag filter and a scrubber before entering the gas engine for further electricity and heat production [45]. The first product gas cooler reduces the product gas temperature from about 820 to $280^{\circ} \mathrm{C}$. The second gas cooler further cools the product gas from $280{ }^{\circ} \mathrm{C}$ to approximately $200-220{ }^{\circ} \mathrm{C}$ by mixing it with the return flow of the cold, clean product gas after the scrubber. The product gas bag filter is used to remove almost all the particulates, which are char, and ash and fine bed materials, from the product gas. The particulates collected in the filter, which are mainly char, are recycled in the combustor as an additional fuel. It is worthwhile to note that a certain amount of fresh bed material (fresh calcined olivine) was continuously added to the gasification system via the combustor, to compensate for the loss of very fine particles of bed material, at approximately $20 \mathrm{~kg} / \mathrm{hr}$.

The final step before entering the gas engine is the scrubbing system. The scrubber completely removes all heavy tars and particulates from the product gas using biodiesel, which is rapeseed methyl ester (RME). The product gas temperature is also reduced by the scrubber from $200-220{ }^{\circ} \mathrm{C}$ to approximately $40{ }^{\circ} \mathrm{C}$ and compressed to 300 mbar as required for the gas engine [45]. The saturated biodiesel flows into the scrubber basin, where the used biodiesel and water are separated. The used biodiesel is also recycled into the combustor as the other additional fuel. The water flows into the 


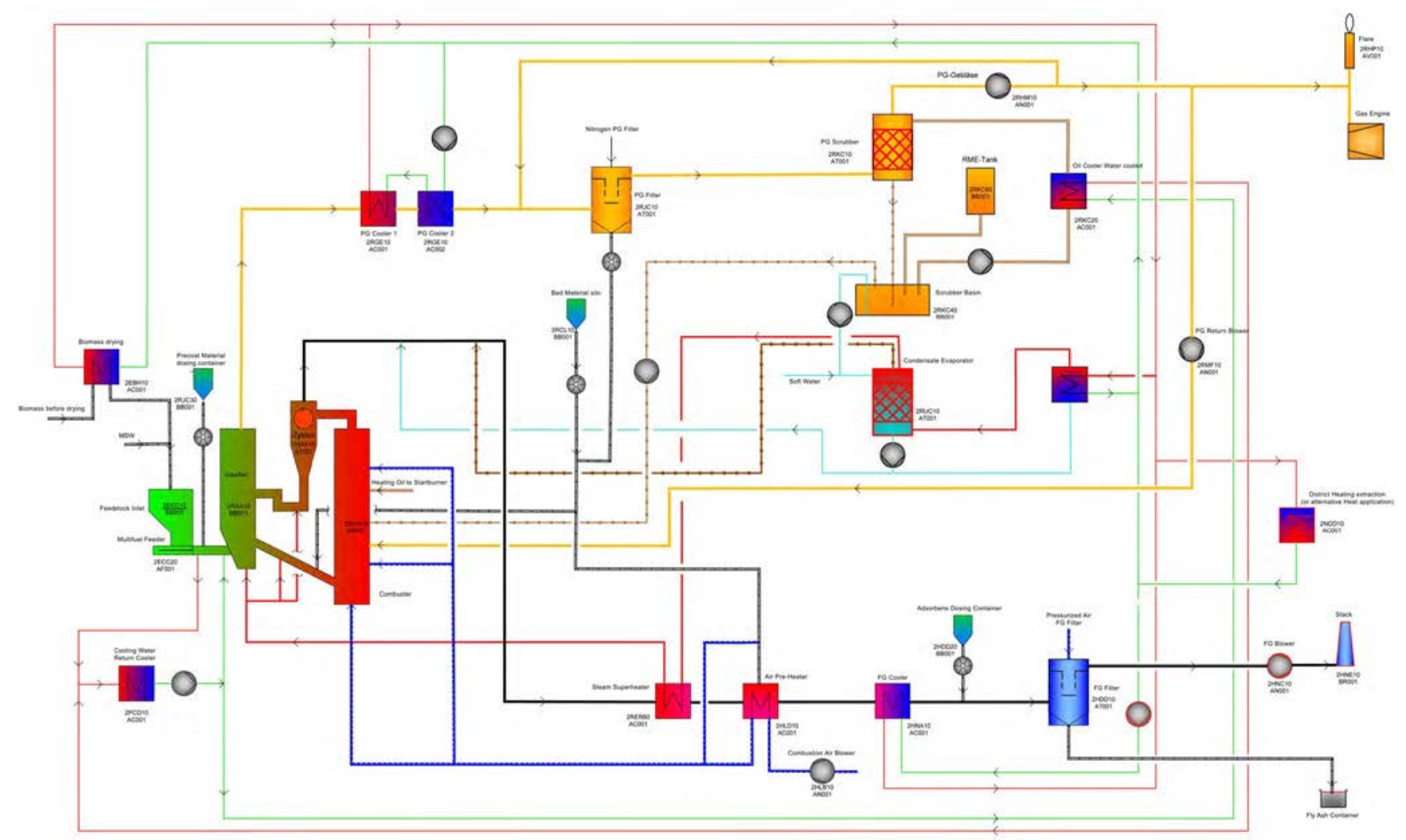

Fig. 3 Schematic diagram of the DFB gasification system in Nong Bua District, Nakhonsawan Province, Thailand [45]

condensate evaporator, where the condensed water is used for steam generation in the gasifier.

For the flue gas, which is generated from the combustor, its sensible heat is used to superheat the steam and preheat air for the gasifier and combustor, respectively. The flue gas then flows to the flue gas cooler, which reduces the temperature of the flue gas to approximately $160-170{ }^{\circ} \mathrm{C}$, before flowing into the flue gas filter and stack, sequentially [45]. The fly ash is collected from the flue gas bag filter for further use in other industries.

The Nong Bua Plant was commissioned in April 2017 and is an improved plant design based on the $8-\mathrm{MW}_{\text {th }}$ DFB gasification system operating in Gussing Plant. The improved operation units in the Nong Bua Plant include the biomass dryer, the gasifier design, the tar scrubber design, the product gas cooler and the flue gas cooling system [15]. With these improvements, the Nong Bua Plant can operate with various biomass feedstocks, including woodchips, cassava rhizomes, sugarcane leaf, rice straw, corn cobs, other agricultural residues and municipal organic solid wastes. In this study, the focus will be on woodchips to establish a benchmark for further comparison with other fuels to be used in the Nong Bua Plant, which can process 30 tonnes per day of woodchips with $40 \%$ moisture content before drying. After drying, random samples of dried wood were taken for moisture content measurement, which was approximately $15-20 \%$. The characteristics of the plant are summarized in Table 2.

\subsubsection{Start-up procedures and operating conditions of the gasifier and combustor}

At start-up, the bed material was first added into the combustor and heated up using supplementary fuel, while the loaded bed material was circulating between the two reactors, until the temperature of the gasifier reached the set point of $820^{\circ} \mathrm{C}$. This start-up process took about $24 \mathrm{~h}$. Then the biomass of woodchips was fed to the gasifier through a screw feeder. When the biomass was first fed to the gasifier, the temperature of both reactors decreased due to the endothermic gasification reactions as mentioned above. However, after a certain period of time, the system reached the steady-state condition in which the temperatures in the gasifier were $800-860{ }^{\circ} \mathrm{C}$, varying

Table 2 Characteristics of the Nong Bua Plant in Thailand [11, 15]

\begin{tabular}{ll}
\hline Characteristics & Value \\
\hline Type of plant & Commercial plant \\
Fuel energy capacity $\left(\mathrm{MW}_{\text {th }}\right)$ & 3.80 \\
Electrical output $\left(\mathrm{MW}_{\mathrm{el}}\right)$ & 1.00 \\
Thermal output $(\mathrm{MW})$ & 1.25 \\
Electrical efficiency & $26.32 \%$ \\
Thermal efficiency & $32.89 \%$ \\
Total efficiency & $59.21 \%$ \\
\hline
\end{tabular}


with the height of the gasifier, and those in the combustor were $870-920^{\circ} \mathrm{C}$. The temperature of the gasifier was measured at the top, middle and bottom of the gasifier during the operation time using layered Chinese olivine and is shown in Fig. 4. The temperatures at each location from top to bottom are called the freeboard temperature, middle-height column temperature and in-bed temperature, respectively. The minor fluctuation is due to noise. The pressure drop in the gasifier and combustor was measured as 110-140 and 80-120 mbar, respectively.

\subsection{Determination of product gas composition and tar concentration}

\subsubsection{Tar sampling points and methods}

Tar in the product gas was sampled, after it had been through the product gas scrubber, for gravimetric tar analysis. The product gas composition and gravimetric tar concentration in the product gas were determined in the experiments where, first, the used Austrian olivine and then the layered Chinese olivine were used.

The gravimetric tar sampling was carried out at preset time intervals using the wet chemical principle following the modified European Standard (EN) DD CEN/TS 15439:2006 "Biomass gasification-Tar and particles in product gasesSampling and analysis". Principally, the method applies five impinger bottles to condense and dissolve the condensable hydrocarbons. Four impinger bottles were filled with toluene of approximately $200 \mathrm{ml}$ per bottle. The fifth bottle was empty, and it was connected to an ABB flow meter and a diaphragm pump. All impinger bottles were kept in a water bath at a temperature of $0-3{ }^{\circ} \mathrm{C}$. The sampling duration depended on the amount of tar collected, which was visually observed. In this study, the dissolved tar samples for gravimetric tar analysis were collected after the heat exchanger and RME scrubber. The samples were collected in quadruple. With temperature probes, the temperature of the product gas in the tar sampling line was heated with trace heating elements, which were set at a constant of $200{ }^{\circ} \mathrm{C}$, approximately. This was to avoid water vapour and tar condensation and loss of analyte. The dissolved tars in the impinger bottles were further extracted using a rotary evaporator until finally only condensable hydrocarbons or gravimetric tars were left. After this, the evaporate bottle was put in an oven at $105^{\circ} \mathrm{C}$ for drying before weighing. Further detail is described by Hongrapipat et al. [45].

\subsubsection{Product gas composition points and analysis}

The product gas was analysed after it had cooled down to 45$55{ }^{\circ} \mathrm{C}$ and the tars were eliminated after the scrubber. Concentrations of methane $\left(\mathrm{CH}_{4}\right)$, carbon monoxide $(\mathrm{CO})$, carbon dioxide $\left(\mathrm{CO}_{2}\right)$ and oxygen $\left(\mathrm{O}_{2}\right)$ were measured online using the $\mathrm{ABB}$ gas analyser, every second. All measured values were presented and stored online in the SCADA system. Other gases including $\mathrm{N}_{2}$ were estimated from previous manual product gas analyses to be $8 \mathrm{vol}$. \%. The percentage of hydrogen in the product gas was determined by calculation from the measured and estimated gases.

\subsection{Feedstock analysis}

In the present study, local Thai woodchips were used as the biomass feedstock. It contains mainly softwood with the
Fig. 4 The gasifier temperature at different heights in the gasification reactor over the operating time when using layered Chinese olivine as the bed material

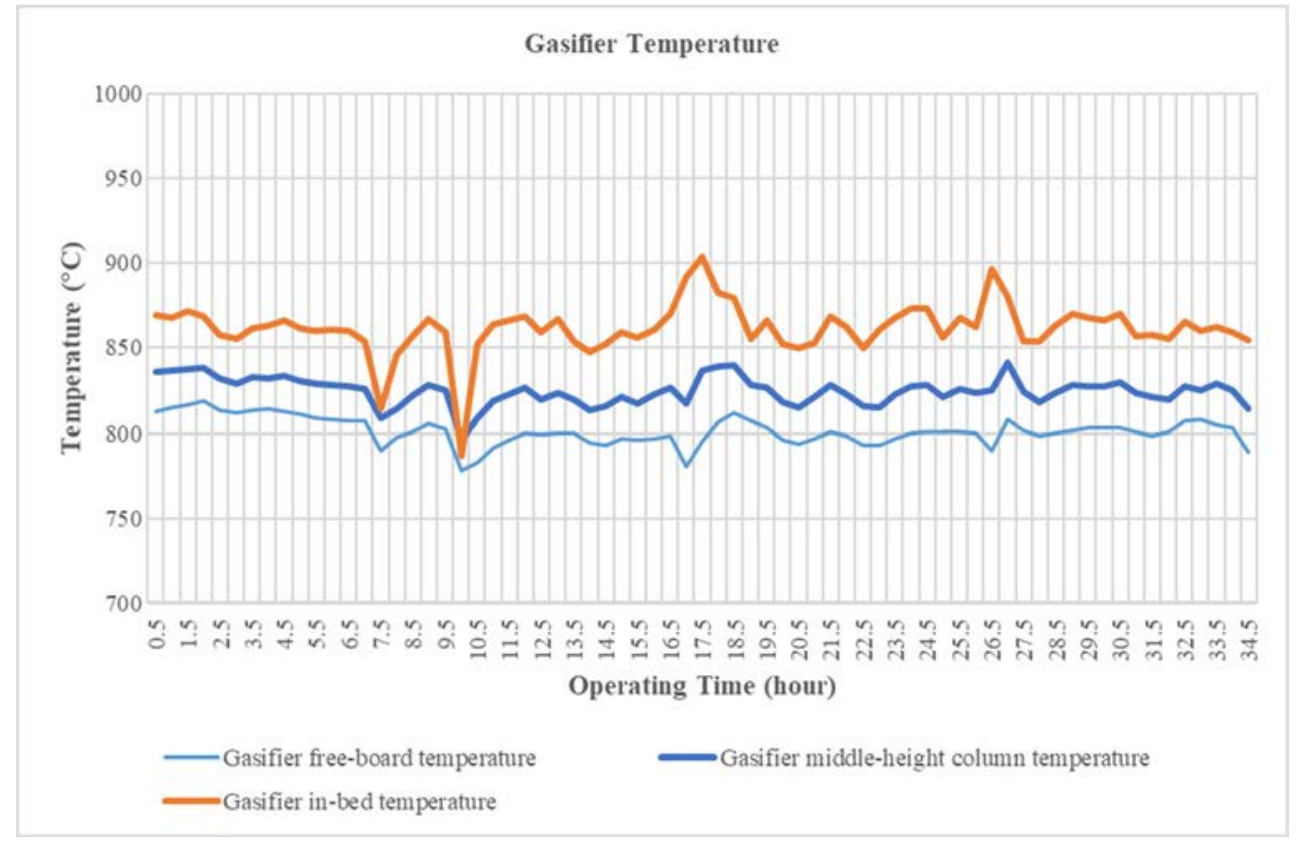


particle cross-section length in a range of $0.5-10 \mathrm{~cm}$. The ultimate analysis, proximate analysis and ash fusion temperature were carried out by SGS (Thailand) Limited. The remaining ash composition collected after the ultimate and proximate analyses was analysed using the X-ray fluorescence spectroscopy (XRF).

\subsection{Bed material sample preparation and characterization}

\subsubsection{Bed material sample preparation}

Bed material samples as received were analysed at the delivery of the olivine. The used bed materials from this study were taken from the bottom of the gasifier of the Nong Bua Plant, after the gasifier and combustor had cooled down during shutdown. Fly ash was also analysed. It was collected from the ash container after the flue gas filter. The olivine and fly ash samples collected were cast using epoxy resin with the addition of carbon powder without any treatment. For the surface morphology analysis, the olivine and fly ash samples were analysed as cast. For the cross-section analysis, the cast olivine samples were polished before characterization. No crosssection analysis was conducted for fly ash.

\subsubsection{Bed material characterization}

Bed materials were analysed regarding their surface morphologically and elemental composition using a Carl Zeiss EVO MA10 scanning electron microscope (SEM) and energy dispersive spectroscopy (EDS). The main composition of the bed material samples measured was magnesium $(\mathrm{Mg})$, silicon $(\mathrm{Si})$, phosphorous $(\mathrm{P})$, potassium $(\mathrm{K})$, calcium $(\mathrm{Ca})$ and iron $(\mathrm{Fe})$. At least three samples collected from different spots of the total samples were analysed, and the average values were used in this study. Carbon and oxygen contents were not analysed.

For fly ash, the analysis method is similar to that of the bed material sample.

Table 3 Gasifier operating temperatures and operating time before the collection of each bed material

\begin{tabular}{lll}
\hline Bed materials & $\begin{array}{l}\text { Gasifier operating } \\
\text { temperatures }\left({ }^{\circ} \mathrm{C}\right)\end{array}$ & $\begin{array}{l}\text { Operating time } \\
\text { (hours) }\end{array}$ \\
\hline $\begin{array}{l}\text { Used Austrian } \\
\text { olivine }\end{array}$ & $800-860$ & 1.7 \\
$\begin{array}{l}\text { Layered Chinese } \\
\text { olivine }\end{array}$ & 34.5 \\
\hline
\end{tabular}

Table 4 Results of proximate and ultimate analysis of woodchips used in this study

\begin{tabular}{|c|c|c|}
\hline & Parameter & Woodchips \\
\hline \multirow{4}{*}{$\begin{array}{l}\text { Proximate analysis } \\
\text { (as-received basis) }\end{array}$} & Moisture (wt \%) & 38.74 \\
\hline & Ash content (wt \%) & 1.39 \\
\hline & Volatile matter (wt \%) & 49.13 \\
\hline & Fixed carbon (wt \%) & 10.74 \\
\hline \multirow{5}{*}{$\begin{array}{l}\text { Ultimate analysis } \\
\text { (dry, ash-free basis) }\end{array}$} & Carbon (C) (wt \%) & 49.64 \\
\hline & Hydrogen $(\mathrm{H})($ wt \%) & 5.98 \\
\hline & Nitrogen (N) (wt \%) & 0.47 \\
\hline & Sulphur (S) (wt \%) & 0.08 \\
\hline & Oxygen $(\mathrm{O})($ wt \%) & 43.83 \\
\hline Lower heating value & LHV (MJ/kg) & 9.89 \\
\hline
\end{tabular}

\section{Results and discussion}

In this article, product gas composition and tar concentration from the DFB steam gasification system of the Nong Bua Plant were characterized when the used Austrian olivine and layered Chinese olivine were used, respectively. In order to investigate the effects of the bed materials, all other operation parameters were controlled at a steady state. Table 3 summarizes the use of bed materials, operating temperature range of the gasifier and operating time before the bed material collection. The used Austrian olivine was used first, but the operation was interrupted due to a high amount of tar in the product gas. The system was stopped, and cleaning was carried out. Therefore, calcium hydroxide and dolomite were added into the gasifier to activate the used Austrian olivine. Later, the fresh Chinese olivine was used to replace the used Austrian olivine, and this developed into layered Chinese olivine. When using the layered Chinese olivine, the Nong Bua Plant performed well. The results of bed material characterization,
Table 5 Summary of $\mathrm{XRF}$ analysis on ash composition of woodchips

\begin{tabular}{ll}
\hline Oxides & Ash analysis (wt \%) \\
\hline $\mathrm{Fe}_{2} \mathrm{O}_{3}$ & 0.93 \\
$\mathrm{MnO}$ & 0.10 \\
$\mathrm{CaO}$ & 40.80 \\
$\mathrm{~K}_{2} \mathrm{O}$ & 15.17 \\
$\mathrm{SO}_{3}$ & 7.18 \\
$\mathrm{P}_{2} \mathrm{O}_{5}$ & 7.93 \\
$\mathrm{SiO}_{2}$ & 13.96 \\
$\mathrm{Al}_{2} \mathrm{O}_{3}$ & 4.86 \\
$\mathrm{MgO}$ & 6.49 \\
$\mathrm{Na}_{2} \mathrm{O}$ & 1.72 \\
$\mathrm{Others}$ & 0.86 \\
Total & 100.0 \\
\hline
\end{tabular}


Ash fusion temperature according to NEN EN 15370 standard

\begin{tabular}{lll}
\hline Phase & Reducing & Oxidizing \\
\hline Initial deformation temperature $\left({ }^{\circ} \mathrm{C}\right)$ & 1405 & 1450 \\
Spherical temperature $\left({ }^{\circ} \mathrm{C}\right)$ & 1420 & 1465 \\
Hemispherical temperature $\left({ }^{\circ} \mathrm{C}\right)$ & 1430 & 1484 \\
Flow temperature $\left({ }^{\circ} \mathrm{C}\right)$ & 1435 & 1500 \\
\hline
\end{tabular}

feedstock analysis and the Nong Bua Plant performance are described below.

\subsection{Feedstock analysis}

Results of the proximate (as-received basis) and ultimate (dry, ash-free basis) analysis for local woodchips are given in Table 4, while the results of the ash composition analysis and ash fusion temperature are summarized in Tables 5 and 6 , respectively.

\subsection{Bed material characterization}

From the past research, it is known that the used calcined olivine has a calcium-rich outer layer, which shows apparent catalyst properties for tar cracking or reforming reactions from the incorporation of wood ash and additives during gasification $[5,9,20,42]$. This has also been verified in this study, both from experience in operating the Nong Bua Plant and from the bed material analysis. In these experiments, the used Austrian olivine from the Gussing Plant was initially requested and shipped to the Nong Bua Plant for its first start-up. This is because it was recommended that the used calcined olivine should be utilized during every start-up period in biomass gasification to minimize tars in the product gas and the used calcined olivine from the previous run should be reused in the next run [11]. With this used Austrian olivine, there should not be a high tar concentration problem in the initial gasification.

\subsubsection{Surface morphology analysis on the bed materials}

Figure 5 shows the SEM images of the used Austrian olivine and layered Chinese olivine collected from the gasifier, and Fig. 6 shows the image of fresh Chinese olivine. In the biomass gasification experiments, the fresh Chinese olivine was mixed with the used Austrian olivine and other additives as aforementioned in Section 2.1. From the SEM, it can be visually observed that the surface of the used Austrian olivine and layered Chinese olivine are smoother compared with the fresh Chinese olivine, due to the attrition inside the combustor and gasifier.

\subsubsection{Elemental composition analysis}

The results of the elemental composition analysis of the used Austrian olivine and layered Chinese olivine collected after the gasification experiments, those bed materials as received from the Gussing Plant for the used Austrian olivine and purchased from China for the fresh Chinese olivine and fly ash are given in Table 7. The images of these bed materials are shown in Fig. 7 for EDS compositional mapping and in Fig. 8 for magnified images.

Considering the used Austrian olivine elemental composition as received, as tabulated in Table 7, a substantial amount of calcium was detected with other main elementals, including magnesium, silicon and iron. Trace amounts of phosphorous and potassium were also observed. In the used Austrian olivine collected after the gasifier, high amounts of magnesium, silicon and iron were observed on the surface of the used Austrian olivine. The EDS result, in the form of mappings and tables, shows a very low amount of calcium of $0.18 \%$ on the surface of the used Austrian olivine. No calcium was observed inside the used Austrian olivine from the elemental analysis of the cross section of the used Austrian olivine. This is in accordance with the findings of Kirnbauer et al. that the calcium-rich layer was observed on the outer layer of the calcined olivine [42].
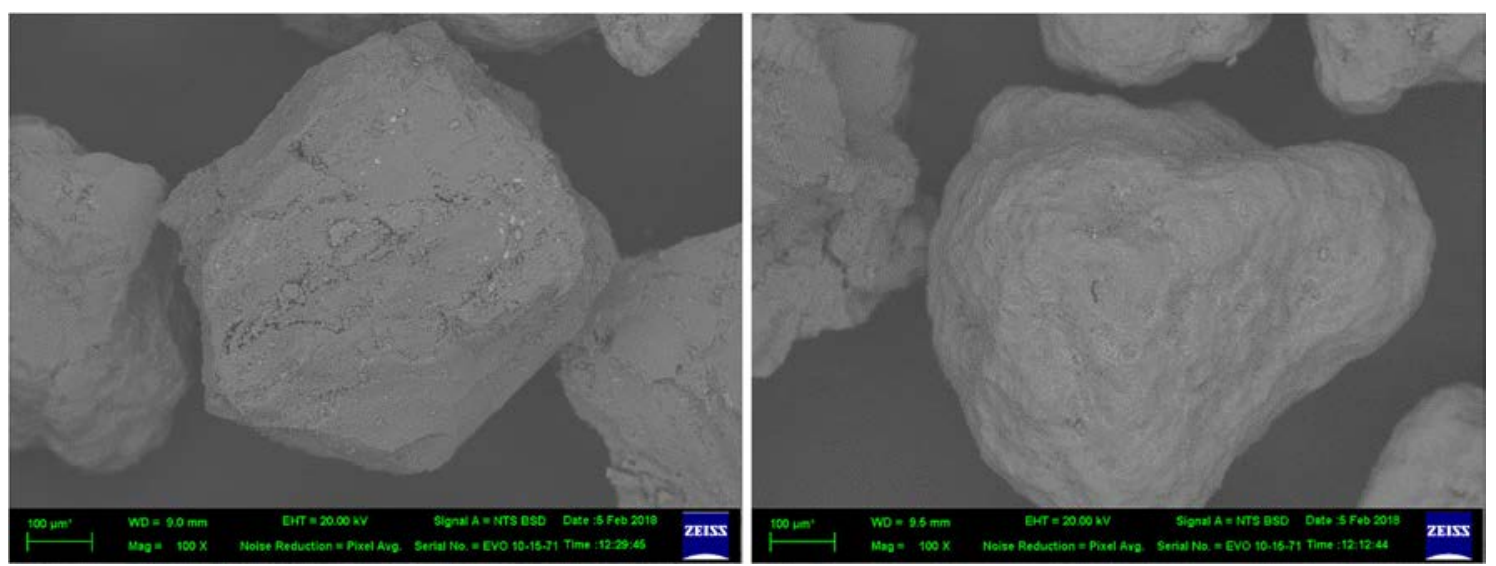

Fig. 5 SEM images of the surface of the used Austrian olivine (left) and the layered Chinese olivine (right) at a magnification of $\times 100$. 


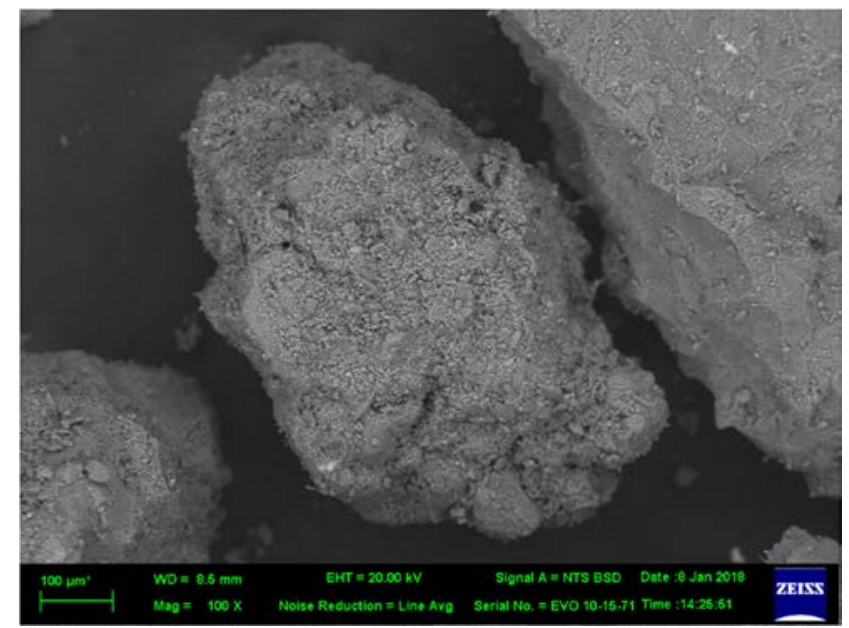

Fig. 6 SEM images of the surface of fresh Chinese olivine at a magnification of $\times 100$

In the layered Chinese olivine, a high amount of calcium was detected on the surface of almost all particles, as shown in Fig. 7 and Table 7. Approximately 9\% of the calcium was detected at the cross section of the layered Chinese olivine, whereas about $45 \%$ of the calcium was observed at the surface of the layered Chinese olivine. The calcium-rich layer was found to be more on the outer layer of the layered Chinese olivine, as shown in the EDS in the form of mapping in Fig. 7 (right).

When comparing the composition of the fresh Chinese olivine obtained from the supplier in weight percentage according to Table 1, and the analysis of fresh Chinese olivine as received using EDS in atomic percentage in Table 7, low calcium was observed with magnesium, silicon and iron as major components.

In both used Austrian olivine and layered Chinese olivine, magnesium, silicon and iron are present because both bed materials have two crystal structures, as aforementionedfayalite $\left(\mathrm{Fe}_{2} \mathrm{SiO}_{4}\right)$ and forsterite $\left(\mathrm{Mg}_{2} \mathrm{SiO}_{4}\right)[19,21,33]$. When comparing the elemental composition on the surface

Table 7 EDS analysis in component atomic percentage (at \%) when using the used Austrian olivine or layered Chinese olivine as the bed materials collected from the gasifier, fly ash collected from the flue gas of the bed materials, collected after each gasifier run, between used Austrian olivine and layered Chinese olivine, the amount of calcium and potassium in the layered Chinese olivine is obviously much higher than that in the used Austrian olivine. As shown in Fig. 8, the outer calcium-rich layer (identified as 2 in the figure) in the layered Chinese olivine is much thicker than that in the used Austrian olivine. However, from the EDS mapping of cross section of the used Austrian olivine, no calcium was observed. This may be due to the limitation of the EDS mapping applied. The calcium in the layered Chinese olivine came from the addition of the aforementioned additives of calcium hydroxide $\left(\mathrm{Ca}(\mathrm{OH})_{2}\right)$, biomass ash $(40 \%$ $\mathrm{CaO})$ and dolomite $\left(\mathrm{CaCO}_{3} \cdot \mathrm{MgCO}_{3}\right)$.

The quantity of magnesium, silicon and iron in the layered Chinese olivine is lower than in the used Austrian olivine. The lower quantity of iron and magnesium observed came from the substitution of calcium for the iron and magnesium [20, 46, 47]. For the used Austrian olivine, the active surface, including the calcium-rich layer of the used Austrian olivine, was removed due to attrition because it was used many times during the Nong Bua Plant commissioning.

Regarding the effect of bed material on tar reduction, it has been reported that the activity of tar cracking in the bed material was related to the mobility of iron at high temperatures $[8,11,20,48]$. From the above reasons, on the one hand, the used Austrian olivine may no longer be active, as there was no calcium; hence it did not indicate the iron or magnesium substitution. On the other hand, the layered Chinese olivine was active, as there was calcium, on which the mobility of the iron and substitution of calcium for iron or magnesium was observed. This is, as mentioned previously, that the amount of iron or magnesium was reduced while the calcium was increased.

Low amounts of calcium were observed on the fresh Chinese olivine before it was developed to the layered Chinese olivine. This is because calcium from the additives

\begin{tabular}{|c|c|c|c|c|c|c|c|c|}
\hline \multirow[t]{3}{*}{ Component } & \multicolumn{4}{|c|}{ Bed materials collected from gasifier } & \multirow{2}{*}{\multicolumn{2}{|c|}{ Bed materials as received }} & \multirow{2}{*}{\multicolumn{2}{|c|}{$\begin{array}{l}\text { Fly ash collected from each } \\
\text { gasifier test run }\end{array}$}} \\
\hline & \multicolumn{2}{|l|}{ Surface } & \multicolumn{2}{|l|}{ Cross section } & & & & \\
\hline & $\begin{array}{l}\text { Used Austrian } \\
\text { olivine }\end{array}$ & $\begin{array}{l}\text { Layered } \\
\text { Chinese olivine }\end{array}$ & $\begin{array}{l}\text { Used Austrian } \\
\text { olivine }\end{array}$ & $\begin{array}{l}\text { Layered } \\
\text { Chinese olivine }\end{array}$ & $\begin{array}{l}\text { Used Austrian } \\
\text { olivine }\end{array}$ & $\begin{array}{l}\text { Fresh Chinese } \\
\text { Olivine }\end{array}$ & $\begin{array}{l}\text { Used Austrian } \\
\text { olivine }\end{array}$ & $\begin{array}{l}\text { Layered } \\
\text { Chinese olivine }\end{array}$ \\
\hline $\mathrm{Mg}$ & 42.42 & 23.93 & 42.95 & 40.33 & 27.74 & 41.30 & 37.37 & 11.33 \\
\hline $\mathrm{Si}$ & 32.77 & 14.14 & 35.80 & 35.86 & 20.81 & 39.53 & 35.13 & 5.93 \\
\hline $\mathrm{P}$ & 0.33 & 2.64 & 0.00 & 0.48 & 1.04 & 0.00 & 0.60 & 2.42 \\
\hline K & 1.01 & 5.24 & 0.00 & 2.60 & 1.13 & 0.00 & 4.45 & 13.85 \\
\hline $\mathrm{Ca}$ & 0.18 & 44.95 & 0.00 & 8.78 & 43.56 & 3.51 & 10.57 & 63.07 \\
\hline $\mathrm{Fe}$ & 23.29 & 9.10 & 21.25 & 11.95 & 11.71 & 15.67 & 11.88 & 3.40 \\
\hline
\end{tabular}

bag filter and the bed materials as received from the Gussing Plant for the used Austrian olivine and purchased from China for the fresh Chinese olivine 
Fig. 7 EDS compositional mapping of the cross section of the used Austrian olivine (left) and the layered Chinese olivine (right) collected after the gasification experiments. The red colour shows the calcium layer

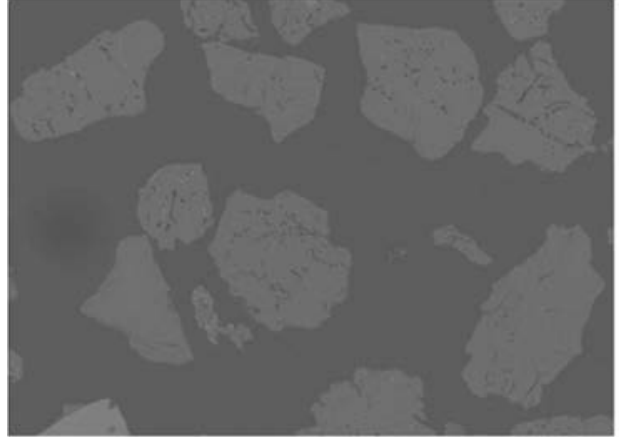

Electron Image 1

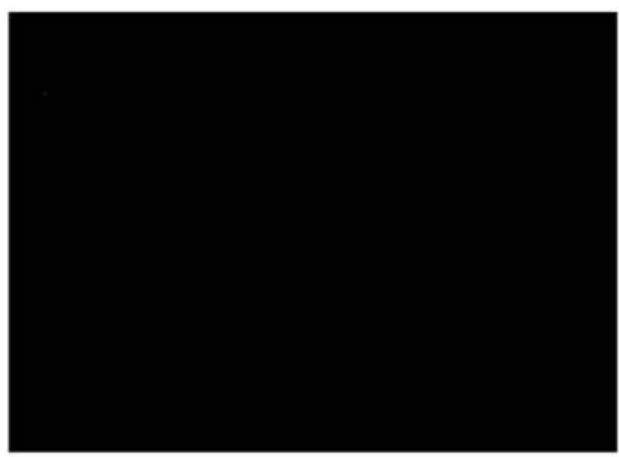

CaKa1

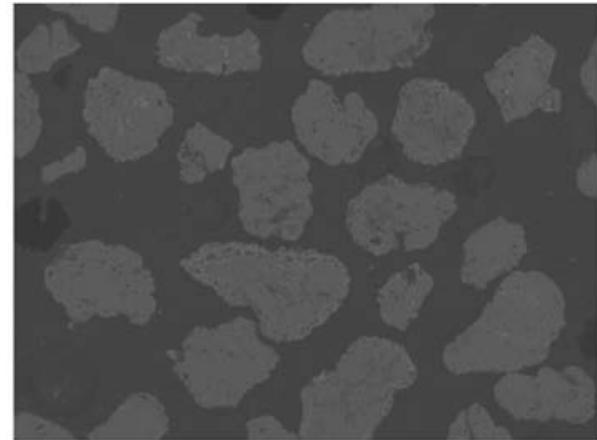

Electron Image 1

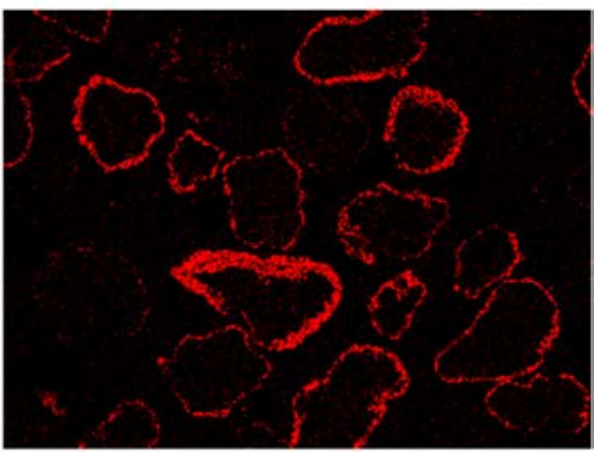

Ca Ka1 requires time to interact and incorporate into the bed material, as the interaction is based on a solid-solid reaction, which in general comes from biomass ash and additives (in this study it is calcium hydroxide and dolomite) $[11,15,20]$. This reaction was observed in the used Austrian olivine as received, which was the used calcined olivine from the Gussing Plant, in which a high amount of calcium was detected. The amount of calcium related to the Nong Bua Plant's performance, as it has been reported to have increased the catalytic activity significantly [5, 9, 49-51], is discussed further.

In the fly ash, calcium was also present in significant amounts. This was confirmed by the fact that certain bed material particles were entrained with the fly ash. The amount of lost bed material depends on the efficiency of the cyclone. A small amount of fly ash was reused in the gasifier as it is a catalyst for the steam gasification system. Additionally, fly ash is used by other industries, mainly in cement in the construction industry $[52,53]$.

\subsection{Determination of product gas composition and tar concentration}

The indicators used to evaluate the Nong Bua Plant performance in this study are gas composition and tar concentration. The measured results for the product gas composition are given in Table 8. Averaged gas composition and its LHV
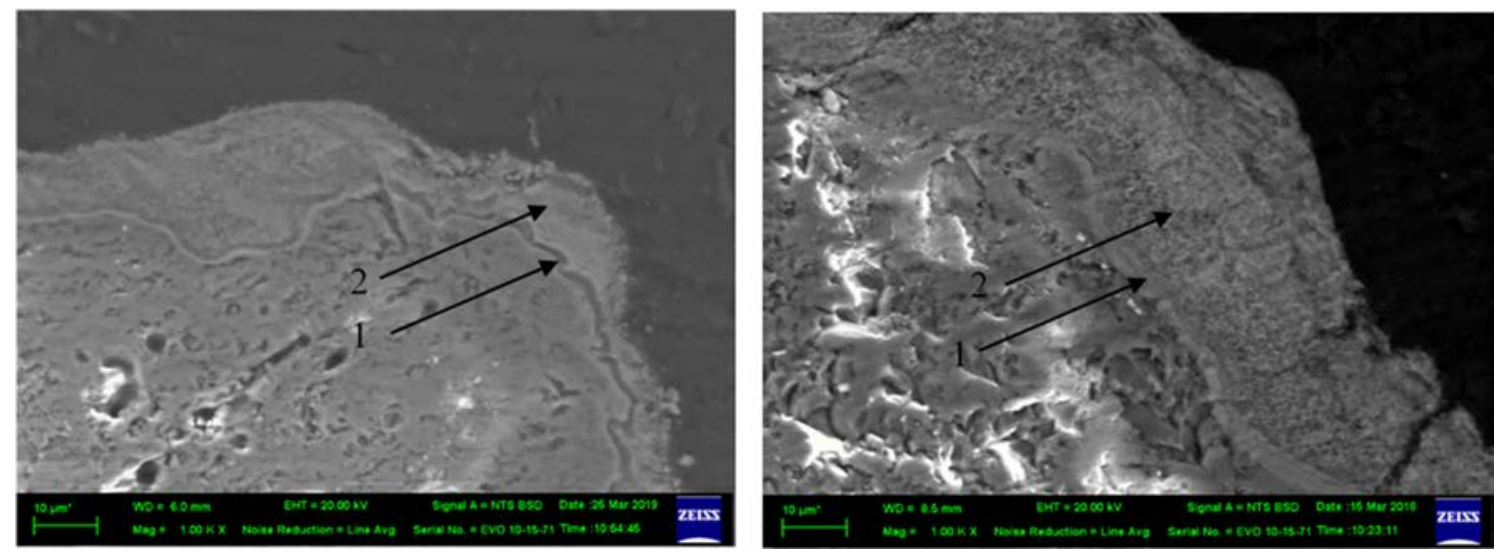

Fig. 8 Magnified SEM images showing an inner layer (1) and an outer layer (2) of the used Austrian olivine (left) and the layered Chinese olivine (right) collected after the gasification experiments. The images have a magnification of $\times 1000$ 
Table 8 Average gas composition, lower heating value (LHV) and tar concentration measured in the biomass gasification experiments

\begin{tabular}{llll}
\hline Gas component/LHV & Design values & Used Austrian olivine & Layered Chinese olivine \\
\hline $\mathrm{H}_{2}($ vol. \%) & $37-40$ & $40.8 \pm 6.8$ & $40.9 \pm 2.2$ \\
$\mathrm{CO}($ vol.\%) & $21-24$ & $26.3 \pm 4.2$ & $22.8 \pm 1.2$ \\
$\mathrm{CO}_{2}($ vol. $\%)$ & $19-23$ & $14.4 \pm 1.5$ & $19.4 \pm 1.5$ \\
$\mathrm{CH}_{4}($ vol. $\%)$ & $9-10$ & $10.5 \pm 1.6$ & $9.0 \pm 0.5$ \\
$\mathrm{LHV}\left(\mathrm{MJ} / \mathrm{Nm}^{3}\right)$ & 13 & $13.7 \pm 0.3$ & $12.7 \pm 0.2$ \\
Average tar $\left(\mathrm{mg} / \mathrm{Nm}^{3}\right)$ & 50 & $1201 \pm 220$ & $872 \pm 125$ \\
\hline
\end{tabular}

values are illustrated in Fig. 9. From the table, it can be found that the gas component contents when using the used Austrian olivine varies from the design values in much wider ranges than the layered Chinese olivine. High tar concentration in the product gas when the Austrian olivine was used is due to low tar reforming and tar cracking activity. The design values are the suggested values of the Nong Bua Plant performance based on mass and energy balance design.

According to Table 8 and Fig. 9, when the layered Chinese olivine was used, the average hydrogen and methane concentrations were $40.9 \pm 2.2$ and $9.0 \pm 0.5 \mathrm{vol} . \%$, respectively. The hydrogen concentration, on average, was in the range of the design value of $37-40 \mathrm{vol} . \%$, while the methane concentration was at the minimum threshold of the design value of 9-10 vol.\%. The lower heating value (LHV) of the product gas was $12.7 \pm 0.2 \mathrm{MJ} / \mathrm{Nm}^{3}$, which was close to the design value of $13 \mathrm{MJ} / \mathrm{m}^{3}$. In Fig. 9, there were some peaks, which may be noise of instruments [44].

The tar concentration in the product gas was lower than that when utilizing the used Austrian olivine, however, still higher than the design value. This indicates that further improvements to the gasification system and the gas cleaning system are needed to reduce tar concentrations in the product gas.

Nevertheless, stable and normal operation, as shown in Fig. 9, was accomplished without a tar accumulation problem for $34.5 \mathrm{~h}$ using the layered Chinese olivine, but further adjustments were required in order to run the gasifier for a longer time. The addition of calcium from biomass ash, calcium hydroxide and dolomite should increase the catalytic activity of the bed material for tar reduction, and hence better performance of the plant with reduced tar level in the product gas is expected. The calcium presented on the layered Chinese olivine indicated that this calcium layer, which replaced the iron and magnesium, is a key parameter for low tar concentration in the product gas.

When comparing the product gas composition as summarized in Table 8 , it was found that the average carbon monoxide and methane concentrations when using layered Chinese olivine were lower than those when using the used Austrian olivine. This indicates the water-gas shift reaction and steammethane-reforming reactions were enhanced with the layered
Fig. 9 The product gas composition over the 34.5 -h operating time using layered Chinese olivine

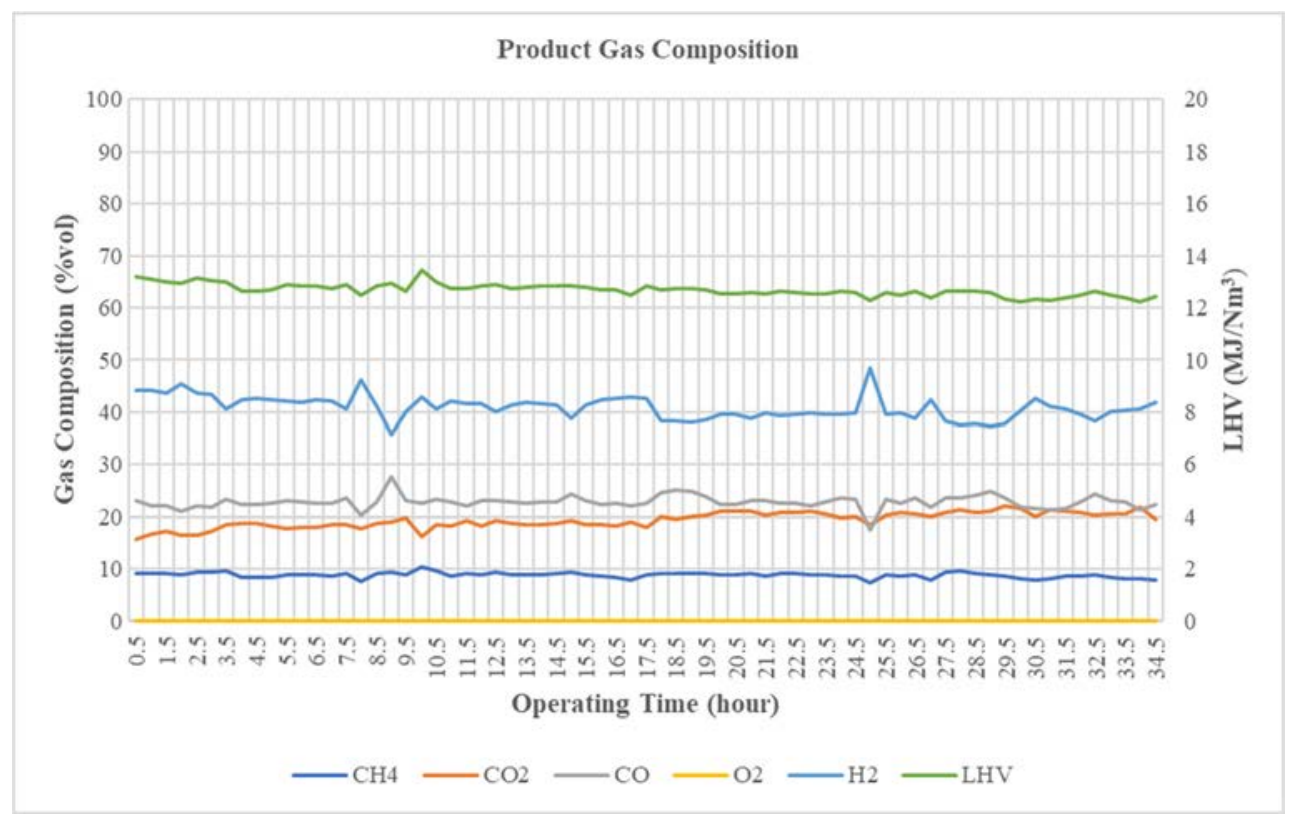


Chinese olivine which promoted hydrogen and carbon dioxide production.

\section{Conclusion}

The activity of bed material was found to influence the performance of the 3.8-MW $\mathrm{MW}_{\text {th }}$ DFB steam gasification system installed in Nong Bua, Thailand. Two sources of bed materials used in the Nong Bua Plant - used Austrian olivine and layered Chinese olivine-were characterized using SEM and EDS techniques. It was found that a very low amount of calcium was observed on the surface of the used Austrian olivine and thus the inactivity of the used Austrian olivine is likely to be due to the attrition of calcium from the outer layer. However, further studies are recommended to confirm this implication.

When the layered Chinese olivine was used, a substantial amount of calcium was detected on the bed material surface, and the Nong Bua Plant operated stably and normally with lower tar concentration in the product gas. Plant performance depends significantly on the activity of bed material, which is related to and characterized by the amount of calcium on the surface of the bed material used in the Nong Bua Plant, and also operation parameters and feedstock properties. The Nong Bua Plant, from this study, will be useful in terms of a benchmark for other agricultural residues in the future.

When layered Chinese olivine was used, the hydrogen on average was in the range of the design value, while the methane concentration was at the minimum threshold of the design value. The lower heating value (LHV) of the product gas was close to the design value. The tar concentration in the product gas was lower than that when using the used Austrian olivine, however still higher than the design value. This indicates that further improvements to the gasification system and the gas cleaning system are needed.

This study determined that the calcined olivine purchased from China can be used to replace the calcined olivine sourced from Austria as long as its composition is similar and the calcium-rich layer is developed on the surface. The calcined olivine purchased from China is more suitable for the Nong Bua Plant in terms of cost, as China is closer to Thailand than Austria. The plant performance of olivine from both sources is expected to be similar when they are activated with additives, i.e. calcium hydroxide, biomass ash and dolomite.

Acknowledgements The authors sincerely thank Markus Koch, the Gussing Plant manager for the successful operation of the Nong Bua Plant during experiments in this article. The authors appreciate support from Christian Henrich, the Nong Bua project manager, for his contribution and Stefan Gunnarsson and Peter Pessl for financial arrangement support. The authors greatly acknowledge King Mongkut's Institute of Technology Ladkrabang (KMITL) Research Fund Grant Number KREF206312 for financial support, and SEM, EDS and tar analysis.
The authors deeply thank TU Wien (TUW) for XRF and XRD analysis, Gussing Renewable Energy (Thailand) Co. Ltd for the support on finance, human resources and data collection and financial support from Michael J. Dichand, International Business Development Shareholder, Gussing Renewable Energy International Holding GmbH.

Availability of data and material The authors declare that all data supporting the findings of this research are available in this article.

Funding information This research was funded by King Mongkut's Institute of Technology Ladkrabang (KMITL) Grant Number KREF206312, Gussing Renewable Energy (Thailand) Co. Ltd and Gussing Renewable Energy International Holding GmbH and Michael J. Dichand, International Business Development Shareholder, Gussing Renewable Energy International Holding $\mathrm{GmbH}$.

\section{Compliance with ethical standards}

Conflicts of interest Not applicable

Ethics approval Not applicable

Consent to participate Not applicable

Consent for publication The authors guarantee that the content in this research has not been previously published elsewhere in whole or in part or submitted at the same time for other publications. However, certain descriptions and images were from other publications. The citations were remarked.

\section{References}

1. Devi L, Ptasinski KJ, Jassen FJJG, Van Paasen SVB, Bergman PCA, Kiel JHA (2005) Catalytic decomposition of biomass tars: use of dolomite and untreated olivine. Renew Energy 30:565-587. https://doi.org/10.1016/j.renene.2004.07.014

2. Baratieri M, Pieratti E, Nordgreen T, Grigiante M (2010) Biomass gasification with dolomite as catalyst in a small fluidized bed experimental and modelling analysis. Waste Biomass Valoriz 1:283291. https://doi.org/10.1007/s12649-010-9034-6

3. Koppatz S, Pfeifer C, Hofbauer H (2001) Comparison of the performance behaviour of silica sand and olivine in a dual fluidised bed reactor system for steam gasification of biomass at pilot plant scale. Chem Eng J 175:468-483. https://doi.org/10.1016/j.cej.2011.09. 071

4. Virginie M, Adenez J, Courson C, De Diego LF, G-Labiano F, Niznansky D, Kiennemann A, Gayen P, Abad A (2012) Effect of $\mathrm{Fe}$-olivine on the tar content during biomass gasification in a dual fluidized bed. Appl Catal B Environ 121-122:214-222. https://doi. org/10.1016/j.apcatb.2012.04.005

5. Kirnbauer F, Wilk V, Kitzler H, Kern S, Hofbauer H (2012) The positive effects of bed material coating on tar reduction in a dual fluidized bed gasifier. Fuel 95:553-562. https://doi.org/10.1016/j. fuel.2011.10.066

6. Pissot S, Vilches TB, Thunman H, Seemann M (2018) Effect of ash circulation on the performance of a dual fluidized bed gasification system. Biomass Bioenergy 115(2018):45-55. https://doi.org/10. 1016/j.biombioe.2018.04.010

7. Department of Alternative Energy Development and Efficiency, Biomass database potential in Thailand (2016) http://weben.dede. go.th/webmax/content/biomass-database-potential-thailand (Accessed 30 March 2016). 
8. Devi L, Craje M, Thüne P, Ptasinski KJ, Janssen FJJG (2005) Olivine as tar removal catalyst for biomass gasifiers: catalyst characterization. Appl Catal A Gen 294:68-79. https://doi.org/10.1016/ j.apcata.2005.07.044

9. Kuba M, Kirnbauer F, Hofbauer H (2017) Influence of coated olivine on the conversion of intermediate products from decomposition of biomass tars during gasification. Biomass Convers Bior 7: 11-21. https://doi.org/10.1007/s13399-016-0204-z

10. Knutsson P, Cantatore V, Seemann M, Tam PL, Panas I (2018) Role of potassium in the enhancement of the catalytic activity of calcium oxide towards tar reduction. Appl Catal B Environ 229:8895. https://doi.org/10.1016/j.apcatb.2018.02.002

11. Siriwongrungson V, Thaveesri J, Pang S, Hongrapipat J, Messner M, Rauch R (2018) Influence of olivine activity on plant performance of a commercial dual fluidized bed gasifier power plant in Thailand. Proc. 2nd Int. Conf. Green Energy and Applications: ICGEA 2018 : Singapore, 24-26, 2018. IEEE, Piscataway (NJ): 23-27. doi:https://doi.org/10.1109/ICGEA.2018.8356294

12. Schmid JC, Pfeifer C, Kitzler H, Pröll T, Hofbauer H (2011) A new dual fluidized bed gasifier design for improved in situ conversion of hydrocarbons. Proc. Int. Conf. Polygeneration Strateg.: Austria. http://pivotalirm.com/files/tech/014.pdf

13. Schmid J C, Pröll T, Pfeifer C, Hofbauer H (2011) Improvement of gas-solid interaction in dual circulating fluidized bed systems. Proc. 9th Eur. Conf. Ind. Furn. Boil. : Portugal

14. Pfeifer C, Schmid JC, Pröll T, Hofbauer H (2011) Next generation biomass gasifier. Proc. 19th Eur. Biomass Conf. Exhib. : Germany. http://pivotalirm.com/files/tech/005.pdf

15. Hongrapipat J, Messner M, Henrich C, Koch M, Nenning L, Rauch R, Hofbauer H (2015) $1 \mathrm{MW}_{\text {el }}$ prototype dual fluidised bed gasifier fuelled with renewable energy resources. Report

16. Pfeifer C, Koppatz S, Hofbauer H (2011) Catalysts for dual fluidised bed biomass gasification - an experimental study at the pilot plant scale. Biomass Convers Bior 1:63-74. https://doi.org/10. 1007/s13399-011-0005-3

17. Kuba M, Hofbauer H (2018) Experimental parametric study on product gas and tar composition in dual fluid bed gasification of woody biomass. Biomass Bioenergy 115:35-44. https://doi.org/10. 1016/j.biombioe.2018.04.007

18. Asadullah M, Miyazawa T, Ito S, Kunimori K, Yamada M, Tomishige K (2003) Catalyst development for the gasification of biomass in the dual-bed gasifier. Appl Catal A Gen 255:169-180. https://doi.org/10.1016/S0926-860X(03)00539-8

19. Devi L, Ptasinski KJ, Janssen FJJG (2003) A review of the primary measures for tar elimination in biomass gasification processes. Biomass Bioenergy 24:125-140. https://doi.org/10.1016/S09619534(02)00102-2

20. Kirnbauer F, Hofbauer H (2013) The mechanism of bed material coating in dual fluidized bed biomass steam gasification plants and its impact on plant optimization. Powder Technol 245:94-104. https://doi.org/10.1016/j.powtec.2013.04.022

21. Corella J, Aznar M, Gil J, Caballero M (1999) Biomass gasification in fluidized bed: where to locate the dolomite to improve gasification? Energy Fuel 13:1122-1127. https://doi.org/10.1021/ ef990019r

22. Rapagna S, Jand N, Kiennemann A, Foscolo P (2000) Steamgasification of biomass in a fluidised-bed of olivine particles. Biomass Bioenergy 19:187-197. https://doi.org/10.1016/S09619534(00)00031-3

23. Corella J, Toledo JM, Padilla R (2004) Olivine or dolomite as inbed additive in biomass gasification with air in a fluidized bed: which is better? Energy Fuel 18:713-720. https://doi.org/10.1021/ ef0340918

24. Berguerand N, Marinkovic J, Vilches TB, Thunman H (2016) Use of alkali-feldspar as bed material for upgrading a biomass-derived producer gas from a gasifier. Chem Eng J 295:80-91. https://doi. org/10.1016/j.cej.2016.02.060

25. Wagner K, Häggström G, Skoglund N, Priscak J, Kuba M, Öhman M, Hofbauer H (2019) Layer formation mechanism of K-feldspar in bubbling fluidized bed combustion of phosphorus-lean and phosphorus-rich residual biomass. Appl Energy 248:545-554. https://doi.org/10.1016/j.apenergy.2019.04.112

26. Berguerand N, Vilches TB (2017) Alkali-feldspar as a catalyst for biomass gasification in a 2-MW indirect gasifier. Energy Fuel 31: 1538-1592. https://doi.org/10.1021/acs.energyfuels.6b02312

27. Florin NH, Harris AT (2008) Enhanced hydrogen production from biomass with in situ carbon dioxide capture using calcium oxide sorbents. Chem Eng Sci 63:287-316. https://doi.org/10.1016/j.ces. 2007.09.011

28. Delgado J, Aznar MP, Corella J (1996) Calcined dolomite, magnesite, and calcite for cleaning hot gas from a fluidized bed biomass gasifier with steam: life and usefulness. Ind Eng Chem Res 35: 3637-3643. https://doi.org/10.1021/ie950714w

29. Dayton D (2002) A review of the literature on catalytic biomass tar destruction. US DOE NREL Report Golden: 32510-32815.

30. Caballero MA, Corella J, Aznar MP, Gil J (2000) Biomass gasification with air in fluidized bed. Hot gas cleanup with selected commercial and full-size nickel-based catalysts. Ind Eng Chem Res 39: 1143-1154. https://doi.org/10.1021/ie990738t

31. Tomishige K, Asadullah M, Kunimori K (2004) Syngas production by biomass gasification using $\mathrm{Rh} / \mathrm{CeO}_{2} / \mathrm{SiO}_{2}$ catalysts and fluidized bed reactor. Catal Today 89:389-403. https://doi.org/10.1016/j. cattod.2004.01.002

32. Pfeifer C, Hofbauer H (2008) Development of catalytic tar decomposition downstream from a dual fluidized bed biomass steam gasifier. Powder Technol 180:9-16. https://doi.org/10.1016/j.powtec. 2007.03.008

33. Yung MM, Jablonski WS, Magrini-Bair KA (2009) Review of catalytic conditioning of biomass-derived syngas. Energy Fuel 23: 1874-1887. https://doi.org/10.1021/ef800830n

34. Scala F, Salatino P (2003) Dolomite attrition during fluidized-bed calcination and sulfation. Combust Sci Technol 175:2201-2216. https://doi.org/10.1080/714923284

35. Morin M, Nitsch X, Hemati M (2018) Interactions between char and tar during the steam gasification in a fluidized bed reactor. Fuel 224:600-609. https://doi.org/10.1016/j.fuel.2018.03.050

36. Riosa MLV, Gonzaelezb AM, Lorab EES, Del Olmoc OAA (2018) Reduction of tar generated during biomass gasification: a review. Biomass Bioenergy 108:345-370. https://doi.org/10.1016/j. biombioe.2017.12.002

37. Rapagnà S, Jand N, Foscolu PU (1998) Catalyst gasification of biomass to produce hydrogen rich gas. Int J Hydrog Energy 23: 551-557. https://doi.org/10.1016/S0360-3199(97)00108-0

38. Rauch R, Bosch K, Hofbauer H, Swierczynski D, Courson C, Kiennemann A (2004) Comparison of different olivines from biomass steam gasification. Proc. 6th Conf. for Science in Thermal and Chemical Biomass Conversion: Canada.

39. Kiennemann A in A V Bridgwater, D G B Boocock (Eds) (2006) Comparison of different olivines for biomass steam gasification. in CPL Press, UK: 799-809

40. Swierczynski D, Courson C, Bedel L, Kiennemann A, Vilminot S (2006) Oxidation reduction behavior of iron-bearing olivine $\left(\mathrm{Fe}_{\mathrm{x}} \mathrm{Mg}_{1-\mathrm{x}}\right)_{2} \mathrm{SiO}_{4}$ used as catalysts for biomass gasification. Chem Mater 18:497-905. https://doi.org/10.1021/cm051433+

41. Kryca J, Priscak J, Łojewska J, Kuba M, Hofbauer H (2018) Apparent kinetics of the water-gas-shift reaction in biomass gasification using ash-layered olivine as catalyst. Chem Eng J 346:113119. https://doi.org/10.1016/j.cej.2018.04.032

42. Kirnbauer F, Hofbauer H (2011) Investigations on bed material changes in a dual fluidized bed steam gasification plant in 
Güssing, Austria. Energy Fuel 25:3793-3798. https://doi.org/10. 1021/ef200746c

43. James AK, Thring RW, Helle S, Ghuman HS (2012) Ash management review-applications of biomass bottom ash. Energies 5: 3856-3873. https://doi.org/10.3390/en5103856

44. Hofbauer H, Rauch R, Bosch K, Koch R, Aichernig C (2002) Biomass CHP plant Güssing - a success story, https://www.tib. eu/en/search/id/BLCP\%3ACN050571944/Biomass-CHP-PlantGussing-A-Success-Story/ 2002 (Accessed 30 March 2016).

45. Hongrapipat J, Siriwongrungson V, Messner M, Hinrich C, Gunnarsson S, Koch M, Dichand M, Rauch R, Pang P, Hofbauer $\mathrm{H}$ (2020) Co-gasification of cassava rhizome and woody biomass in the $1 \mathrm{MWel}$ prototype dual fluidized bed gasifier by Gussing renewable energy. IOP Conf Series: Earth and Environmental Science 495. https://doi.org/10.1088/1755-1315/495/1/012019

46. Libourel G (1999) Systematics of calcium partitioning between olivine and silicate melt: implications for melt structure and calcium content of magmatic olivines. Contrib Mineral Petrol 136:63-80. https://doi.org/10.1007/s004100050524

47. Kuba M, Kirnbauer F, Skoglund N, Boström D, Öhman M, Hofbauer H (2016) Mechanism of layer formation on olivine bed particles in industrial-scale dual fluid bed gasification of wood. Energy Fuel 30:7410-7418. https://doi.org/10.1021/acs. energyfuels.6b01522

48. Devi L, Ptasinski KJ, Janssen FJJG (2005) Pretreated olivine as tar removal catalyst for biomass gasifiers: investigation using naphthalene as model biomass tar. Fuel Process Technol 86:707730. https://doi.org/10.1016/j.fuproc.2004.07.001

49. Kuba M, Havlik F, Kirnbauer F, Hofbauer H (2006) Influence of bed material coatings on the water-gas-shift reaction and steam reforming of toluene as tar model compound of biomass gasification. Biomass Bioenergy 89:40-49. https://doi.org/10.1016/j. biombioe.2015.11.029

50. Kuba M, Kirnbauer F, Skoglund N, Bostrom D, Ohman M, Hofbauer H (2016) Thermal stability of bed particle layers on naturally occurring minerals from dual fluid bed gasification of woody biomass. Energy Fuel 30:8277-8285. https://doi.org/10.1021/acs. energyfuels.6b01523

51. Kern S, Pfeifer C, Hofbauer H (2013) Reactivity tests of the watergas shift reaction on fresh and used fluidized bed materials from industrial DFB biomass gasifiers. Biomass Bioenergy 55:227-233. https://doi.org/10.1016/j.biombioe.2013.02.001

52. Tang Z, Ma S, Ding J, Wang Y, Zheng S, Zhai G (2013) Current status and prospect of fly ash utilization in China. World of Coal Ash Conf., USA

53. Tiwari MK, Bajpai S, Dewangan UK (2016) Fly ash utilization: a brief review in Indian context. Int J Res Eng Technol 3:949-956 
Karlsruher Institut für Technologie

\section{Repository KITopen}

Dies ist ein Postprint/begutachtetes Manuskript.

\section{Empfohlene Zitierung:}

Siriwongrungson, V.; Hongrapipat, J.; Kuba, M.; Rauch, R.; Pang, S.; Thaveesri, J.; Messner, M.; Hofbauer, $\mathrm{H}$.

Influence of bed materials on the performance of the Nong Bua dual fluidized bed gasification power plant in Thailand.

2020. Biomass Conversion and Biorefinery.

doi: $\underline{10.5445 / / R / 1000122490}$

Zitierung der Originalveröffentlichung:

Siriwongrungson, V.; Hongrapipat, J.; Kuba, M.; Rauch, R.; Pang, S.; Thaveesri, J.; Messner, M.; Hofbauer, $\mathrm{H}$.

Influence of bed materials on the performance of the Nong Bua dual fluidized bed gasification power plant in Thailand.

2020. Biomass Conversion and Biorefinery.

doi:10.1007/s13399-020-00908-6 